\title{
モデル粗骨材を用いたコンクリートの圧縮強度についで
}

\author{
小阪 義 *** 谷川恭 雄 $^{* * *}$ 太田福 男****
}

\section{Compressive Strength of Concrete with Cubic Aggregate of Cement Mortar}

\author{
by \\ Yoshio Kosaka, Yasuo TANIGAwA \\ (Faculty of Engineering, Nagoya University, Nagoya) \\ and Fukuo Oota \\ (Faculty of Engineering, Meijo University, Nagoya)
}

The purpose of this experimental study is to investigate the strength of concrete having the cubic aggregates of cement mortar under uniaxial compression. The cement mortar aggregate with and without thin coating of paraffin were provided respectively, to examine the effect of bond between aggregate and mortar matrix on the compressive strength of concrete. The cylindrical concrete specimens of $\phi 10 \times 20 \mathrm{~cm}$ were made by mixing the above mentioned aggregate and the cement mortar, and were tested at the age of 28 days of concrete.

The test results are summarised as follows;

(1) The bond strength between the aggregate without paraffin coating and the mortar matrix was about $13-14 \mathrm{~kg} / \mathrm{cm}^{2}$.

(2) The bond strength between the paraffin coated aggregate and the mortar matrix was almost zero.

(3) The compressive strength of concrete decreased with increase of the volume fraction of aggregate in concrete, regardless of the surface condition of aggregate.

(4) The compressive strength of concretes hardly increased in spite of increase of the compressive strength of aggregate, expect the concrete having lower volume fraction of aggregate than 0.2.

(5) The compressive strength of concrete having the aggregate with paraffin coating was only about 20-25 percent of the strength of concrete having the uncoated aggregate, under higher volume fraction of aggregate in concrete than 0.45 .

(Received Sep. 22, 1970)

\section{1 緒言}

最近, コンクリート用骨材の需要が急激に増加して いるが，大都市周辺では川砂・川砂利の入手が次第に 困難になってきている。そのため, 砕石や各種の人工 軽量骨材など，使用骨材の種類が多様化するとともに， これらの骨材の使用量がますをす増加する傾向にある。 このような傾向にそなえて，各種の骨材を用いたコン クリートの力学的諸性質を骨材性質などをパラメータ として, 総括して説明しうるょうな一般的な強度理論 ならびに変形理論を確立することるま圷重要な研究課 題の一つではないかと思われる.

その一つの試みとして, 最近コンクリートを異種材 料からなる混合複合材料とみなして，その力学性質を

\footnotetext{
* 原稿受理 昭和45年 9 月22日

** 正会員 名古屋大学工学部 名古屋市千種区不老町

*** 名古屋大学工学部 名古屋市千種区不老町

**** 名城大学理工学部 名古屋市昭和区天白町八事裏山
}

解明しようとする研究が多くみられるようになってき た、筆者らもこのような観点から、 コンクリートのや ング係数，ポアソン比执よび引張強度などにおよぼす 骨材の影響について検討してきたが，本論では，これ ら一連の基礎的研究の一つとして行なったモデル骨材 を用いたコンクリートの圧縮強度に関する実験とその 結果について報告する。

コンクリートの生縮強度に执よぼす骨材の影響に関 する最近の研究としては, 主として骨材粒径の影響に ついて検討した Walker · Bloem, Cordon - Gillespie, Hughes. Chapman, 高橋 • 中根, 川上, Johnston な ぞの研究, 骨材量の影響について検討したBache, 大 井, 岡島, 川上などの研究, 骨材の表面状態の影響に ついて検討した Kaplan, 米沢・河合, Johnston の研究，骨材強度の影響について検討したBache, 爾 見・島谷, 村田などの研究, 骨材の付着強度の影響に 
ついて検討した Shah, Nepper-Christensen • Nielsen などの研究がある.

一般に，コンクリートの圧縮強度は母材（セメント ペーストまたはモルタル）の強度, 骨材強度特よび母 材と骨材間の付着強度などによって左右される。顕微 鏡およびX線などによる観察に基づいた Cornell 大学 に拈ける一連の研究によれば，骨材と母材との界面に は, 荷重を加える以前にかなりのひびわれが発生して おりコンクリートの強度上この部分が最も弱点とな りやすいことを明らかにしている。したがって，母材 と骨材間の付着特性の解明とその評価方法についての 研究は, コンクリートの強度理論を確立するための最 も重要な課題の一つといえる。しかし, 上述のごとく 主として骨材の付着強度がコンクリートの圧縮強度に およぼす影響について調べた研究はいまのところ Nepper-Christensen・Nielsen の研究など一，二を数壳 るにすぎない。

そのため, 本報では主として母材と骨材間の付着特 性がコンクリートの圧縮強度に和よぼす影響について 調べるために，モルタル製の立方形モデル骨材を使用 したコンクリートを製作して，下記のような実験的研 究を行なった。

\section{$2 \cdot 1$ 実験の概要}

\section{2 実 験 万 法}

コンクリートの圧縮強度に执よぽす骨材の付着特性, 粗骨材容積比, 骨材強度などの影響について調べるた めに, Table I に示すような各種のコンクリート試験 体を用いて実験を行なった。すなわら，

（1）試験体の形状 - 寸法 ; $\phi 10 \times 20 \mathrm{~cm}$ 円柱体,

Table I. Test program

\begin{tabular}{|c|c|c|c|c|}
\hline $\begin{array}{l}\text { Notation of } \\
\text { concrete }\end{array}$ & $\begin{array}{l}\text { W/C* of } \\
\text { mortar } \\
\text { matrix }\end{array}$ & $\begin{array}{l}\text { W/C* of } \\
\text { coarse } \\
\text { aggregate }\end{array}$ & $\begin{array}{l}\text { Texture of } \\
\text { coarse } \\
\text { aggregate }\end{array}$ & $\begin{array}{l}\text { Volume } \\
\text { fraction of } \\
\text { coarse } \\
\text { aggregate in } \\
\text { concrete }\end{array}$ \\
\hline $35 \mathrm{H} \mathrm{U}$ & \multirow{4}{*}{$35 \%$} & \multirow{2}{*}{$40 \%$} & Uncoated & 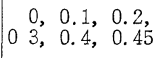 \\
\hline $35 \mathrm{HC}$ & & & Coated & " \\
\hline $35 \quad \mathrm{~L} \mathrm{U}$ & & \multirow{2}{*}{$50 \%$} & Uncoated & " \\
\hline $35 \mathrm{LC}$ & & & Coated & " \\
\hline $40 \mathrm{HU}$ & \multirow{4}{*}{$40 \%$} & \multirow{2}{*}{$40 \%$} & Uncoated & " \\
\hline $40 \mathrm{HC}$ & & & Coated & " \\
\hline $40 \mathrm{~L} \mathrm{U}$ & & \multirow{2}{*}{$50 \%$} & Uncoated & " \\
\hline 40 L C & & & Coated & " \\
\hline $50 \mathrm{HU}$ & \multirow{4}{*}{$50 \%$} & \multirow{2}{*}{$40 \%$} & Uncoated & " \\
\hline $50 \mathrm{HC}$ & & & Coated & " \\
\hline $50 \mathrm{~L} \mathrm{U}$ & & \multirow{2}{*}{$50 \%$} & Uncoated & " \\
\hline 50 L C & & & Coated & " \\
\hline
\end{tabular}

（2）母材モルタルの水セメント比； $35 ， 40$ 杼よび50 $\%$ の 種類,

（3）モデル粗骨材の水セメント比； 40 执よび $50 \%$ の 2 種類,

（4）母材と骨材との付着特性; 粗骨材の表面にパラ フィンを塗布したもの（以下，被覆骨材という）と塗 布しないもの (以下, 無処理骨材という) の 2 種類,

（5）粗骨材容積比； $0 ， 0.1 ， 0.2 ， 0.3 ， 0.4$ 抢よび 0.4506 種類,

とし，上記 (1) (5) の各要因を組み合わせて合計 216 個の試験体を製作した。

\section{$2 \cdot 2$ 使用材料}

コンクリート拈よびモデル骨材の製作には，普通ポ ルトランドセメント（4 週圧縮強度 $=408 \mathrm{~kg} / \mathrm{cm}^{2}, 4$ 週曲げ強度 $=70.7 \mathrm{~kg} / \mathrm{cm}^{2}$ ) 拈よび木兽川産の川砂（比 重 $=2.48$, 粗粒率 $=3.08$, 吸水率 $=2.46 \%$ ）を用いた。 また，コンクリートの製作には，粗骨材としてモルタ ル製のモデル粗骨材を用いた。ここに，粗骨材として モルタル製の骨材を使用したのは，骨材製作時にモデ ル骨材と同種モルタルを用いた標準試験体を製作して おくことにより，骨材の強度和よび変形性質が手軽に 調ベられるためである。な拉，本報ではモデル骨材は すべて $2 \mathrm{~cm}$ 角の立方体とした。モデル骨材の製作に 用いたモルタルの水セメント比は40拉よび50\%の 2 種 類とし, セメント一砂比はすべて 1.0 (容積比) とし た.これらのモデル骨材はいずれも打設後約 24 時間実 験室内に放置し，その後材令 27 日目まで水温 $20^{\circ} \pm 1^{\circ} \mathrm{C}$ の恒温水そう中で湌生した。また，母材との付着特性 の異なった骨材を得るために，モデル骨材をあらかじ め溶融パラフィン液に浸し, 骨材表面にパラフィン被 覆（厚さ約 $0.4 \mathrm{~mm}$ ) を施した骨材と,これらの処理 を施さない無処理骨材とを作成した。モデル骨材のコ ンクリート製作時に和ける材令は28日である。

\section{$2 \cdot 3$ コンクリートの調合および試験体の製作方法}

コンクリートの調合表を Table II に示す。な挔, すべての調合に和いて母材モルタルのセメント一砂比 は 1.0 (容積比)とした。

モデル骨材自体およびパラフィン被膜の破損を防ぎ, あわせて打設コンクリート中の骨材容積比を正確に保 つために，つぎのような練りまぜ方法を用いた。すな わち, あらかじめ内部を水でしめらせた強制練りミキ サ(容量 $50 \mathrm{l}$ ) 内に, 細骨材 (注ぼ表乾状態), 七メ ントの順に投入し，約 5 分間から練りしたのち，水を 投入してまず母材モルタルを作成した。その後むらか じめ計量して和いた粗骨材を母材モルタル中に投入し， 手練り法で混練した。な执, コンクリートの締め固め には外部振動機を使用した。

試験体はコンクリートの打設後約 48 時間は室温 $20^{\circ}$ 
Table II. Mix proportions of concrete.

\begin{tabular}{|c|c|c|c|c|c|c|}
\hline $\begin{array}{l}\text { Notation } \\
\text { of } \\
\text { concrete }\end{array}$ & $\begin{array}{l}\mathrm{W} / \mathrm{C}^{*} \\
(\%)\end{array}$ & $V_{a} / V_{c} * *$ & $\begin{array}{c}\text { Water } \\
\left(\mathrm{kg} / \mathrm{m}^{3}\right)\end{array}$ & $\begin{array}{l}\text { Cement } \\
\left(\mathrm{kg} / \mathrm{m}^{3}\right)\end{array}$ & $\left|\begin{array}{l}\text { Fine } \\
\text { aggregate } \\
\left(\mathrm{kg} / \mathrm{m}^{3}\right)\end{array}\right|$ & $\begin{array}{l}\text { Coarse } \\
\text { aggregate } \\
\left(\mathrm{kg} / \mathrm{m}^{3}\right)\end{array}$ \\
\hline $35 \mathrm{HU}$ & \multirow{6}{*}{35} & 0 & 351 & 1006 & 792 & 0 \\
\hline & & 01 & 309 & 884 & 696 & 220 \\
\hline $35 \mathrm{HC}$ & & 02 & 274 & 782 & 616 & 440 \\
\hline $35 \mathrm{~L} \mathrm{U}$ & & 0.3 & 238 & 680 & 536 & 660 \\
\hline \multirow{2}{*}{$35 \mathrm{~L} \mathrm{C}$} & & 04 & 203 & 575 & 456 & 880 \\
\hline & & 045 & 185 & 528 & 416 & 990 \\
\hline \multirow{2}{*}{$40 \mathrm{HU}$} & \multirow{6}{*}{40} & 0 & 383 & 956 & 753 & 0 \\
\hline & & 0.1 & 336 & 841 & 662 & 220 \\
\hline $40 \mathrm{HC}$ & & 02 & 298 & 744 & 586 & 440 \\
\hline $40 \mathrm{LU}$ & & 0.3 & 259 & 647 & 510 & 660 \\
\hline \multirow{2}{*}{$40 \mathrm{~L} \mathrm{C}$} & & 0.4 & 220 & 551 & 434 & 880 \\
\hline & & 0.45 & 201 & 502 & 396 & 990 \\
\hline \multirow[t]{2}{*}{$50 \mathrm{HU}$} & \multirow{6}{*}{50} & 0 & 437 & 872 & 687 & 0 \\
\hline & & 01 & 383 & 767 & 604 & 220 \\
\hline $50 \mathrm{HC}$ & & 02 & 339 & 679 & 534 & 440 \\
\hline $50 \mathrm{~L} \mathrm{U}$ & & 0.3 & 295 & 590 & 465 & 660 \\
\hline \multirow{2}{*}{$50 \mathrm{~L} \mathrm{C}$} & & 0.4 & 251 & 502 & 395 & 880 \\
\hline & & 0.45 & 229 & 458 & 361 & 990 \\
\hline
\end{tabular}

* Water-cement ratio of mortar matrix

** Volume fraction of coarse aggregate in concrete

$\pm 3^{\circ} \mathrm{C}$, 相対湿度 $80 \% \pm 5 \%$ の養生室内で空中養生を行 ない，その後材令27日目までは標凖水中養生を行なっ た。コンクリート試験体はすべて材令28日目（モデル 骨材の試験時材令は56日）飞実験に供した。

\section{$2 \cdot 4$ 試験方法}

コンクリート，母材モルタルおよびモデル骨材の圧 縮強度は JIS A 1108 の規定 $(\phi 10 \times 20 \mathrm{~cm}$ 円柱体使 用）に準じて求めた。な拈，母材モルタル执よびモデ ル骨材については，上記の試験方法の泳かに， JIS R 52010 規定に準じた圧縮および曲げ試験法 $(4 \times 4 \times 16$ $\mathrm{cm}$ 角柱体使用）によってそれぞれの強度を求めた。

また，母材モルタルとモデル骨材間の付着特性を求 めるために，本報では便宜上Alexander などによる 曲げ試験方法を用いた。な特，付着強度測定法の試験 体の製作に際しては，あらかじめ製作しておいた骨材 と新たに打設する母材との接着面が打設方向と平行に なるようにした。

\section{3 実験結果とその考察}

本実験で得られた母材モルタル和よびモデル骨材の 圧縮強度ならびに引張強度 $(\phi 10 \times 20 \mathrm{~cm}$ 円柱形試験 体による)，母材モルタルとモデル骨材との付着強度 の一覧を Table III に示す.

\section{$3 \cdot 1$ 母材モルタルとモデル骨材との付着強度}

曲げ試験法によって求めた無処理骨材と母材モルタ ルとの付着強度 $\left(F_{b}\right)$ と母材の水セメント比 (W/C) との関係をFig. 1 に示す。な括，Fig. 1 にはAlexander, Hsu・Slate，福田などの実験結果を併示してあ る、また，図中の持よび○印はそれぞれ母材がモ几 タルおよびセメントペーストの場合の結果であること
Table III. Test results of mortar matrix and coarse aggregate.

\begin{tabular}{c|c|c|c|c|c}
\hline $\begin{array}{l}\text { Notation of } \\
\text { concrete }\end{array}$ & $\begin{array}{r}F_{c m^{*}} \\
\left(\mathrm{~kg} / \mathrm{cm}^{2}\right)\end{array}$ & $\begin{array}{r}F_{t m^{* *}} \\
\left(\mathrm{~kg} / \mathrm{cm}^{2}\right)\end{array}$ & $\begin{array}{r}F_{c a^{* * *}} \\
\left(\mathrm{~kg} / \mathrm{cm}^{2}\right)\end{array}$ & $\begin{array}{r}F_{b}^{* * * *} \\
\left(\mathrm{~kg} / \mathrm{cm}^{2}\right)\end{array}$ & $F_{c a} / F_{c m}$ \\
\hline $35 \mathrm{H}$ & 550 & 282 & 403 & 140 & 0.73 \\
$35 \mathrm{~L}$ & 575 & 31.0 & 255 & - & 0.44 \\
$40 \mathrm{H}$ & 466 & 26.1 & 509 & 130 & 1.09 \\
$40 \mathrm{~L}$ & 500 & 287 & 272 & - & 0.54 \\
$50 \mathrm{H}$ & 433 & 24.3 & 403 & 13.2 & 093 \\
$50 \mathrm{~L}$ & 475 & 268 & 278 & - & 059
\end{tabular}

* Compressive strength of mortar matrix

** $\quad$ Splitting tensile strength of mortar matrix

*** Compressive strength of coarse aggregate

**** Bond strength between mortar matrix and coarse aggregate

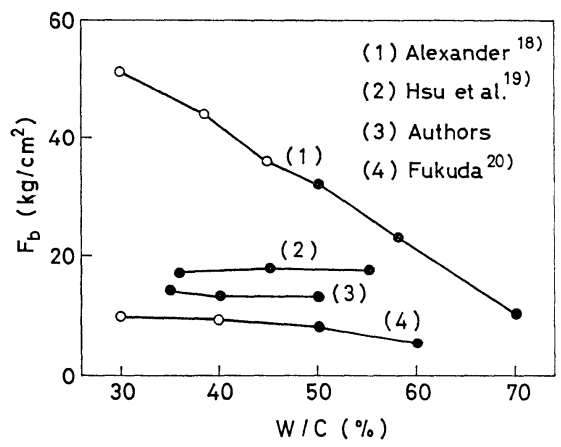

Fig. 1. Relationship between $F_{b}$ and W/C (Where, $F_{b}$; bond strength between matrix and aggregate, W/C ; water-cement ratio of matrix).

を示す. Fig. 1 中に示した各研究者の結果は, 骨材性 質, 母材の打設方向, 試験体の責生方法, 材令, 試 験方法なとがそれぞれ相違するため，これらの值を 直接比較するのは無意味であるが，Fig.1 によれ ば，Alexander の結果を除けば，付着強度は母材の 水セメント比によってあまり相違しないことがわか る.

な特，本報に抢けるような曲げ試験法あるいは他の 研究にみられるよ5な直接引張試験法などによって求 めた母材と骨材間の付着強度と, コンクリート中に混 入された骨材と母材間の実際の付着強度との関連につ いては，いまの之ころ不明の点が多く，早急に解決す べき問題であると考光る。

今回の実験によって得られた無処理骨材と母材モル タルとの曲げ付着強度は，母材モルタルの圧縮強度の 約 $2.5 \sim 3.0 \%$, 引張強度の約40〜60\%であった. 一方， 被覆骨材の場合付着強度はすべて零であった。

\section{$3 \cdot 2$ 試験体の破壊状況}

コンクリート試験体の破壞状況は使用骨材の種類と その使用量によって若干相違した。すなわち, 無処理 
骨材を用いた試験体では，骨材容積比 $\left(V_{a} / V_{c}\right)$ が小 さい場合 $\left(V_{a} / V_{c}=0.1 \sim 0.2\right)$ 飞は試験体端部にすべ り破壞面がみられたが， $V_{a} / V_{c}$ の值が大きい場合には 荷重の増加とともに試験体中央部付近に縦ひびわれが 発生し，その後やや荷重が増大してから破壞した。な お， $V_{a} / V_{c}$ 值の小さい試験体では骨材が破壊したもの もかなりみられた。

一方，被覆骨材を用いた試験体では，骨材容積比の 大きさにかかわらず，試験体端部でのすべり破壊面の 形成が注とんどみられず，試験体側面に縦ひびわれが 発生すると同時に破壊を生じた。この場合，モデル骨 材の破壊は汪とんど観察されなかった。

\section{$3 \cdot 3$ コンクリートの圧縮強度と骨材容積比との関 係}

コンクリートの压縮強度 $\left(F_{c c}\right)$ と骨材容積比 $\left(V_{a}\right)$ $V_{c}$ ) との関係をFig. 2 に示す。ただし，Fig. 2 の縦軸 はコンクリートの圧縮強度と母材モルタルの圧縮強度 との比 $\left(F_{c c} / F_{c m}\right)$ を表わしている.Fig. 2 によれ゙, 無処理骨材拉よび被覆骨材コンクリートに対する $F_{c c} /$ $F_{c m}$ の值は $V_{a} / V_{c}$ の増加に伴って減少し，とくに被 覆骨材コンクリートの圧縮強度は $V_{a} / V_{c}$ の值が約 $0.4 \sim 0.45$ 程度になると, 母材モルタルの圧縮強度の 約10\%程度にまで低下する。また，無処理骨材コンク リートの $F_{c c} / F_{c m}$ の值は $V_{a} / V_{c}$ の増加とともにほぼ 直線的に減少するのに対して, 被覆骨材コンクリート の $F_{c c} / F_{c m}$ 值は $V_{a} / V_{c}$ が0.1の場合にすでに約 0.5 にまで減少し，この值は無処理骨材コンクリートの $V_{a} / V_{c} \doteqdot 0.45$ の場合に注ぼ相当する。充，図中の直 線はコンクリート試験体の横断面に打ける骨材切断面 積比が各試験体の骨材容積比に等しく，かつ骨材の強 度を零と仮定した場合の仮想的な圧縮強度を示するの であるが，今回の実験によって得られた环縮強度はこ の直線で表示される值を下迴っている.これは，コン クリートのような非均質なぜい性材料は一般に試験体 中の最も弱い経路を通ってひびわれが発生して破壊に

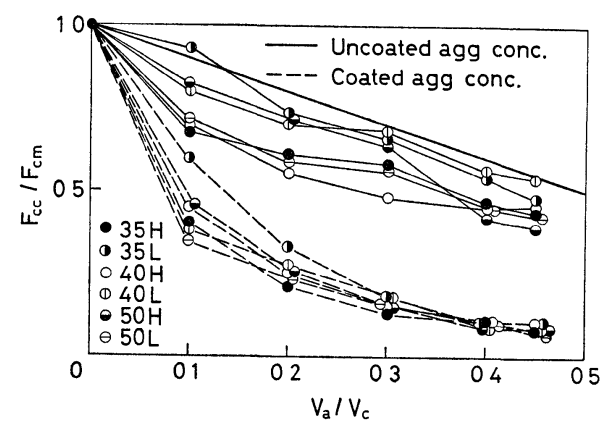

F1g. 2. Relationship between $F_{c c} / F_{c m}$ and $V_{a} / V_{c}$, (Where, $F_{c c}$; compressive strength of concrete, $F_{c m}$; compressive strength of mortar matrix and $V_{a} / V_{c}$; volume fraction of coarse aggregate).
至ること，母材中に，母材とはヤング係数の異なる材 料を混入すると，その境界面にかなり大きな局部的引 張応力が生じる可能性があることなどが原因と思われ る・

つぎに，無処理骨材コンクリートに関する本実験結 果と下記の各研究者によって求められたコンクリート の圧縮強度と骨材容積比との関係を表わす式との比較 をFig. 3 に示す。

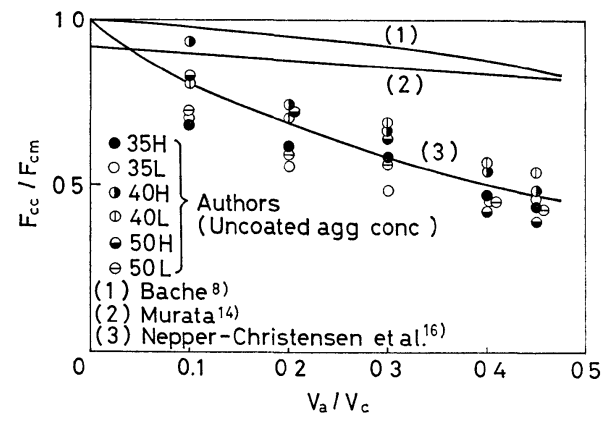

Fig. 3. Relationship between $F_{c c} / F_{c m}$ and $F_{c a} / F_{c m}$, (Where, $F_{c c}, \quad F_{c a}$ and $F_{c m}$ are compressive strengthes of concrete, coarse aggregate and mortar matrix, respectively).

Bache 式; $; \frac{F_{c c}}{F_{c m}}=\left(\frac{F_{c a}}{F_{c m}}\right)^{V_{a} / V_{c}}$

村田式; $\frac{F_{c c}}{F_{c m}}=\frac{F_{c a}}{F_{c m}}\left[\frac{V_{a}}{V_{c}}+m\left(1-\frac{V_{a}}{V_{c}}\right)\right]$

Nepper-Christensen . Nielsen 式;

$$
\frac{F_{c c}}{F_{c m}}=\frac{{ }_{c} F_{c c}}{F_{c m}}\left[1+b\left(\frac{V_{a}}{V_{c}}\right)\right]
$$

ここに, $F_{c c} ;$ コンクリートの圧縮強度

$F_{c m} ;$ 母材の圧縮強度

$F_{c a} ;$ 骨材の圧縮強度

${ }_{c} F_{c c} ;$ 被覆骨材コンクリートの圧縮強度

$V_{a} / V_{c} ;$ 骨材容積比

$$
\begin{gathered}
m \text {; 母材之骨材のヤング係数の比 } \\
b \text {; 付着強度係数 (実験定数) }
\end{gathered}
$$

Fig. 3 によれば，本実験值は村田式拈よびBache式 による值よりもかなり小さい。これは両式が比較的球 形に近い軽量骨材を使用したコンクリートについて求 められた式であるのに対して，本実験では立方形骨材 を用いたため，骨材の比表面積が球形骨材に比べて大 きく，付着による破壊が生じやすいこと，骨材の隅角 部に応力集中が起こり, 早期の局部的破壞を起こしや すいことなどに起因するものと思われる。な执， Nepper-Christensen - Nielsen 式は本実験結果とよく一 致しているが，これは付着強度係数 $b$ （実験定数）の 值を本実験結果に基ついて決めたためである。

\section{$3 \cdot 4$ コンクリートの圧縮強度と骨材の圧縮強度と の関係}


コンクリートの圧縮強度 $\left(F_{c c}\right)$ と骨材の圧縮強度 $\left(F_{c a}\right)$ との関係をFig. 4 に示す。ただし，図ではそれ ぞれの圧縮強度を母材モルタルの圧縮強度 $\left(F_{c m}\right)$ で 除して無次元表示してある。また，図中に示した $F_{c a}$ の值は $\phi 10 \times 20 \mathrm{~cm}$ 試験体によって求めた見かけの骨 材強度である。Fig. 4 にみられるように，測定結果は かなりばらついて拈り，この結果に基づて骨材強度 とコンクリート強度間の相関関係の詳細を論じること は因難である．今回の実験の範囲内では，使用骨材の 種類にかかわらず，骨材容積比 $\left(V_{a} / V_{c}\right)$ が比較的小 さい場合を除いては，骨材強度の増大によるコンクリ 一ト強度の明確な向上を認めることはできなかった。 たとえば，パラフィン被覆骨材を用いたコンクリート の場合, $V_{a} / V_{c}$ の值が 0.1 执よび 0.2 のコンクリート の圧縮強度は, 骨材強度とともにわずかに増大する傾 向を示したが， $V_{a} / V_{c}$ の值が 0.3 よりる大きいコンク リートの圧縮強度は, 骨材強度の大きさにかかわらず, 注ほ定の值を示した。をた，図中にも示したように， 前述の Bache 式特よび村田式によれば，コンクリー 卜強度は骨材強度とともに増大するが, 今回の実験結 果は，無処理骨材和よび被覆骨材のいずれの骨材を用 いた場合も,これらの実験式の示す結果とは著しく相 違した。 その原因としては，使用骨材の形状，表面状 態などの相違が考えられるが，この点に関してはさら に詳しい検討が必要である。

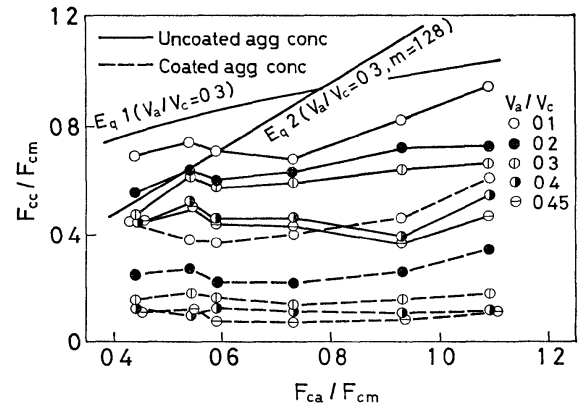

Fig. 4. Relationship between $F_{c c} / F_{c m}$ and $V_{a} / V_{c}$ (Comparison between test results by authors and those by other investigators).

\section{$3 \cdot 5$ コンクリートの圧縮強度と骨材の表面状態と の関係}

同一シリーズの被覆骨材コンクリートの圧縮強度と 無処理骨材コンクリートの圧縮強度の比 $\left({ }_{c} F_{c c} /{ }_{u} F_{c c}\right)$ と骨材容積比 $\left(V_{a} / V_{c}\right)$ との関係を Fig. 5 に示す.

Fig. 5 によれば，被覆骨材コンクリートの圧縮強度 $\left({ }_{c} F_{c c}\right)$ は無処理骨材コンクリートの圧縮強度 $\left({ }_{u} F_{c c}\right)$ に比べて著しく小さく,その差は $V_{a} / V_{c}$ が増大するに つれて大きくなる。ただし， $V_{a} / V_{\mathrm{c}}$ が約 0.4 よりも大

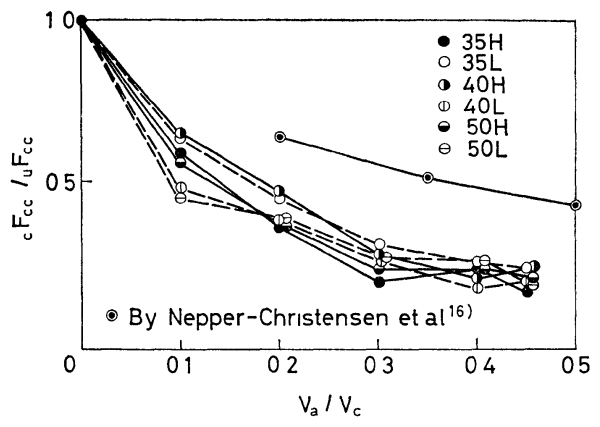

F1g. 5. Relationship between ${ }_{c} F_{c c} /{ }_{u} F_{c c}$ and $V_{a} / V_{c}$, (Where, ${ }_{c} F_{c c}$; compressive strength of coated aggregate concrete, ${ }_{u} F_{c c}$; compressive strength of uncoated aggregate concrete and $V_{a} / V_{c}$; volume fraction of coarse aggregate).

きくなると, ${ }_{c} F_{c c} /{ }_{u} F_{c c}$ の值は約0.2〜0.25程度の一定 值に近づく傾向が見られる。図中には Nepper-Christensen ・ Nielsen によるガラス玉を骨材として使用し た場合の実験結果も併示してあるが，これらの実験值 は今回の実験結果よりもかなり大きい。

なお, ${ }_{c} F_{c c} /{ }_{u} F_{c c}$ と $V_{a} / V_{c}$ との関係には, 母材の水 セメント比, 骨材強度などによる顕著な相違は見られ なかった。

$3 \cdot 6$ コンクリートの圧縮強度と水セメント比との 関係

コンクリートの圧縮強度 $\left(F_{c c}\right)$ と母材モルタルの水 セメント比 (W/C) との関係をFig. 6 に示す. 図中の 曲線はJASS 5 による水セメント比と圧縮強度との関 係式（普通セメント， $\beta=1.0, K=370 \mathrm{~kg} / \mathrm{cm}^{2}$ として 算定）を示している. Fig. 6 によれば，無処理骨材コ
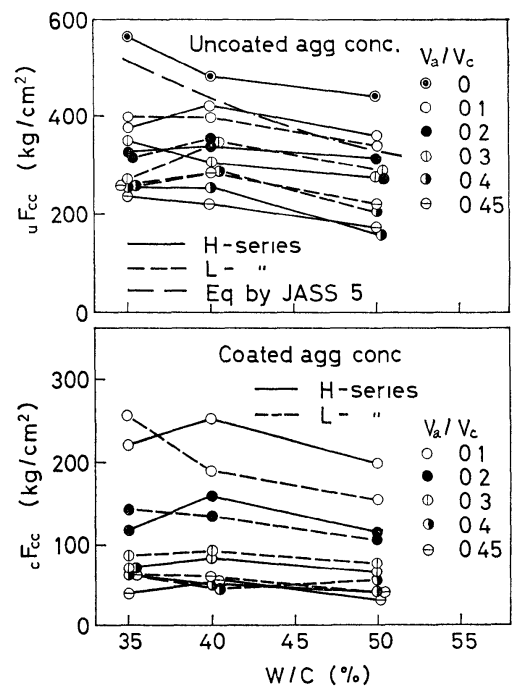

Fig. 6. Relationship between $F_{c c}$ and W/C, (Where, $F_{c c}$; compressive strength of concrete and $\mathrm{W} / \mathrm{C}$; water-cement ratio of mortar matrix). 
ンクリートの圧縮強度は水セメント比の増加とともに やや減少するが，その減少率はJASS式によるそれよ りも小さい。また，骨材容積比が零すなわち母材モル タルのみの縮強度は JASS 式による值よりやや大き いが， $V_{a} / V_{c}$ が約 0.2 より大さい場合の圧縮強度は JASS 式による值よりもかなり小さい。これは本実験 の場合, ほとえどすべての試験体に执いてモデル骨材 の強度の方が母材モルタルの強度よりも小さかったこ とも一つの原因と思われる. (Table III 参照)

一方，パラフィン被覆骨材コンクリートの圧縮強度 も, 水セメント比 (W/C) の増加とともにやや減少す る傾向がみられたが，その減少の割合はさ注ど著しく はない，とくに， $V_{a} / V_{c}$ の值が比較的大きい範囲（約 0.3〜0.45）では，W/Cの值にかかわらず，コンクリ ート強度はほぼ一定值を示した。これはコンクリート 試験体の破壊が洭とんど母材と骨材間の付着特性のみ に支配されたためであろう。

\section{4 結論}

コンクリートの王縮強度に扣よぼす骨材容積比, 骨 材強度, 骨材の付着特性などの影響について調べるた めに，モルタル製のモデル骨材を用いて実験を行なっ た、その結果，特よそつぎのようなことが明らかとな った。

（1）曲げ試験法によって求めた母材モルタルと無処 理骨材との付着強度は, 今回の実験に関する限り, 母 材の水セメント比にかかわらず，湾湾 $13 \sim 14 \mathrm{~kg} / \mathrm{cm}^{2}$ の一定となった。

（2）コンクリートの圧縮強度と母材モルタルの圧縮 強度との比は骨材容積比の増加とともに減少し, 骨材 容積比が約 $0.4 \sim 0.45$ の場合では, 無処理骨材コンク リートで約 0.5 , パラフィン被覆骨材コンクリートで 約 0.1 となった。

（3）骨材強度とコンクリート強度との相関はあまり 明りょろではなかった。ただし，骨材容積比が約 0.2 よりも小さい範囲では, 使用骨材の種類にかかわらず, コンクリートの圧縮強度は骨材強度の増加とともにえ ずかに増加する傾向を示した。

（4）パラフィン被覆骨材コンクリートと無処理骨材 コンクリートの压縮強度の比は骨材容積比の増加とと もに著しく減少し, 骨材容積比が約 $0.4 \sim 0.45$ の場合 では約 $0.2 \sim 0.25$ の程度となった。

(5) パラフィン被覆骨材ュンクリートの圧縮強度は

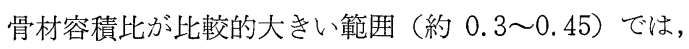
母材モルタルの水セメント比にかかわらず, 各容積比 ごとにほぼ一定值を示した。

今回の実験は立方形のモデル骨材を用いた模型実駩 であるため，上記の結果を通常の骨材を使用したコン クリートにそのまま適用することはできない。な拉，
上記の実験結果に対する理論解析手法, コンクリート 中に混入された骨材の強度および母材と骨材間の付着 強度の測定方法などについては，今後さらに検討を行 なら予定である。

\section{参 考 文 献}

1）小阪義夫, 谷川恭雄, 太田福男, セメント技術年報, XXII, 260 (1968)；セメントコンクリート, No. 284, 9 (1970).

2) Walker, S, and D.L. Bloem, J. of ACI, 57, No.3, 283 (1960).

3) Cordon, W.A., and H.A. Gillespie, J. of ACI. 60, No. 8, 1029 (1963).

4) Hughes, B.P., and G.P. Chapman, Mag. of Conc. Res., 18, No. 54, 19 (1966).

5) 高橋久雄, 中根 淳, 材料, 18, No. 185, 79 (1969).

6）川上英男, 日本建築学会論報, No.166, 19 (1969); No. 167, 7 (1970).

7) Johnston, C.D., Mag. of Conc. Res., 22, No. 70, 5 (1970).

8) Bache, H. H., Proc. of RILEM Symp. of Testing and Design Methods of Lightwerght Aggregate Concretes, 9 (1967).

9）大井孝和，セメント技術年報，XXII, 371 (1968).

10）岡島達雄, コンクリートジャーナル， 8, No.1, 2 (1970).

11) Kaplan, M.F., J. of ACI, 55, No.11, 1193 (1959).

12）木沢久兵衛, 河合清一, セメント技術年報, XVIII, 448 (1964).

13）爾見軍治，渔谷宏文，セメント技術年報，XXI，321 (1967).

14）村田二郎, 神山行男, セメント技術年報, XXII, 223 (1968).

15) Shah, S.P., and S. Chandra, J. of ACI, 65, No.9, 770 (1968).

16) Nepper-Christensen, P., and T.P.H. Nielsen, J. of ACI, 66, No.1, 69 (1969).

17) Hsu, T.T.C., F.O. Slate, G.M. Sturman, and G. Winter, J. of ACI, 60, No.2, 209 (1963); Hsu, T. T.C., J. of ACI, 60, No.3, 371 (1963); Slate, F.O., and S. Olsefsk1, J. of ACI, 60, No.5, 575 (1963); Sturman, G.M., S.P. Shah, and G. Winter, J. of ACI, 62, No. 7, 805 (1965), Shah, S. P., and G. Winter, J. of ACI, 63, No.9, 925 (1966).

18) Alexander, K. M., Proc. of the First Tewksbury Symp., 141 (1963).

19) Hsu, T.T.C., and F.O. Slate, J. of ACI, 60, No. 4, 465 (1963).

20）福田礼一郎, 日本建築学会論報, No.140, 7 (1967). 